\title{
Simultaneous determination of 5 diuretic drugs using a HPLC method by quantitative analysis of multi-components by single-marker
}

\section{Fuchao Chen}

Dongfeng General Hospital

\section{Baoxia Fang}

Dongfeng General Hospital

peng Li ( $\square$ dfyylp@163.com )

Dongfeng General Hospital

\section{Sicen Wang}

Xi'an Jiaotong University

\section{Research Article}

Keywords: Diuretic drug, Multi-components with a single marker, HPLC, Method development

Posted Date: February 24th, 2021

DOI: https://doi.org/10.21203/rs.3.rs-230869/v1

License: (9) This work is licensed under a Creative Commons Attribution 4.0 International License. Read Full License 


\section{Simultaneous determination of 5 diuretic drugs using a HPLC method by quantitative analysis of multi-components by single-marker}

Fuchao Chen ${ }^{1}$, Baoxia Fang ${ }^{1}$, Peng $\operatorname{Li}^{1 *}$, and Sicen Wang ${ }^{2 *}$

1 Sinopharm Dongfeng General Hospital, Hubei University of Medicine, Shiyan, Hubei, 442008, P.R. China. 2 School of Pharmacy, Xi'an Jiaotong University, Xi'an, 710061, Shanxi, PR China.

Fu-chao Chen and Baoxia Fang contributed equally to this work and should be considered as equal first authors.

Correspondence to: Peng Li, E- mail: dfyylp@163.com. Sinopharm Dongfeng General Hospital, Hubei University of Medicine, Shiyan, Hubei, 442008, P.R. China.Sicen Wang, E-mail: wangsc@mail.xjtu.edu.cn. School of Pharmacy, Xi'an Jiaotong University, Xi'an, 710061, Shanxi, PR China. 


\section{Abstract:}

Background: Loop diuretics is commonly used in clinical practices to manage the high fluid load and to control fluid balance. In this paper, a quantitative analysis of multiple components with a single marker (QAMS) method was firstly developed for simultaneous determination of 5 diuretic drugs including furosemide, torasemide, azosemide, etacrynic acid, and bumetanide by HPLC. The qualitative analysis was performed using relative capacity factor and ultraviolet (UV) spectral similarity as the double indicator. The QAMS method was conducted with etacrynic acid as an internal reference substance. The other four diuretics were calculated by using the relative correction factors for etacrynic acid. The contents of the 5 diuretic drugs were also determined by the external standard method (ESM). The chromatographic separation was achieved on an Shimadzu HC-C 18 column $(150 \mathrm{~mm} \times 4.6 \mathrm{~mm}, 5 \mu \mathrm{m})$ using $50 \mathrm{mM}$ of potassium dihydrogen phosphate ( $\mathrm{pH}$ adjusted to 4.0 with phosphoric acid) with acetonitrile $(64: 36, \mathrm{v} / \mathrm{v})$ as mobile phase at the flow rate of $1.0 \mathrm{ml} / \mathrm{min}$ and a column temperature of $30^{\circ} \mathrm{C}$.

Results: Under these conditions, the 5 diuretic drugs are well separated, showing linear relationships within certain ranges. The quantitative results showed that there was no significant difference between the QAMS and ESM method.

Conclusions: Overall, the HPLC-QAMS analytical scheme established in this study should be a simple, efficient, economical, and accurate method for quantitative evaluation of 5 diuretic drugs.

Keywords: Diuretic drug; Multi-components with a single marker; HPLC; Method development 


\section{Introduction}

Loop diuretics (LDs) are a kind of drug prescribed widely in clinical practices to manage the high fluid load and to control fluid balance [1]. LDs pharmacologic action is blocking the $\mathrm{Na}^{+}-\mathrm{K}^{+}-2 \mathrm{Cl}^{-}$co-transporter which transfusions from the tubular lumen in to the tubular cells. They inhibit $\mathrm{Na}^{+}$and $\mathrm{Cl}^{-}$reabsorption in the thick ascending limb of the loop of Henley and cause increased secretion of water, $\mathrm{K}^{+}, \mathrm{Na}^{+}$, and $\mathrm{Cl}^{-}[2]$. Furosemide, torasemide, azosemide, bumetanide, and etacrynic acid are examples of this class of diuretics [3].

Furosemide (Fig 1a), a 5-sulfamoylbenzoic acid derivative LD, has been the most widely prescribed with regard to administration via continuous infusion and the chemical name is 5-(Aminosulfonyl) -4-chloro-2-([2-furanylmethyl] amino) benzoic acid [4]. Torasemide (Fig 1b), a non-acidic LD has a long half-life, long time of action, and higher bioavailability compared to the other LD, which the chemical name is 1-[4-(3-methylphenyl) aminopyridine-3-based] sulfonyl- 3- isopropylurea [5]. Azosemide (Fig 1c), [2-chloro-5-(1H-tetrazole-5-yl)-N4-(2-thenyl) sulfanila- mide], is a sulfonamide LD, which is used clinically in the treatment of oedema of various genesis and hypertension [6]. Bumetanide (Fig 1d), a 5- sulfamoylbenzoic acid derivative LD, and chemical name is 3- (Aminosulfonyl)-5- (butylamino)- 4phenoxybenzoic acid [7]. Etacrynic Acid (Fig 1e), [2, 3- dichloro-4- (2-methylenebutyryl) phenoxy)-acetic acid], is chemically different from all other known diuretic agents, which is now mainly used in patients with severe sulfonamide allergy that prohibit the use of other LDs [8].

Nowadays some analytical methods have been reported by HPLC for the quantification of furosemide, torasemide, azosemide, bumetanide, or etacrynic acid either alone or in combination with other drugs in its pharmaceutical dosage forms and in biological fluids [9-21]. All of the above-mentioned methods, however, have not been employed for the simultaneous quantification of the five LDs in any pharmaceutical formulation. QAMS method is able to simultaneously determine the concentrations of multi-components by a single reference standard, which greatly reduces the cost and reduction of the analysis time of the experiment [22-29]. Thus, the present study was to develop a rapid HPLC-QAMS method for the determination of the five LDs. The developed QAMS method was evaluated by comparing the calculated results with an ESM method. This method has been successfully applied to 
quality evaluation of formulas of the five LDs in hospital.

\section{Experimental}

\subsection{Materials and reagents}

Five reference substances (furosemide, torasemide, azosemide, bumetanide, or etacrynic acid) were obtained from the National Institutes for Food and Drug Control (Beijing, China). The purity of each of the five reference substance was more than 99\%. Chromatographic grade of Methanol and acetonitrile were purchased from Kemiou Chemical Reagent Co., Ltd. (Tianjin, China). AR grade of potassium dihydrogen phosphate $\left(\mathrm{KH}_{2} \mathrm{PO}_{4}\right)$, triethylamine, and phosphoric acid were obtained from Sinopharm Chemical, Shanghai, China. The pharmaceutical formulations containing furosemide, torasemide, azosemide, bumetanide, or etacrynic acid were obtained commercially.

\subsection{Apparatus and analytical conditions.}

Chromatographic separations were achieved on Agilent HPLC 1260 system equipped with diode array-detector (G4212B), auto sampler (G1329B), a quaternary pump (G1311C), and a Column Oven (G1316A). A digital workstation with total ChemStation software Version $\underline{\text { C.01.10 }}$ serves as both a controller and data manager for the overall system. Shimadzu HC-C 18 column $(150 \mathrm{~mm} \times 4.6 \mathrm{~mm}, 5 \mu \mathrm{m})$ was applied during the study under the following analytical conditions: the mobile phase was composed of acetonitrile with $0.05 \mathrm{~mol} / \mathrm{L}$ of $\mathrm{KH}_{2} \mathrm{PO}_{4}(\mathrm{pH}$ adjusted to 4.0 using diluted phosphoric acid) (36: 64, v/v) under the detection wavelength at $260 \mathrm{~nm}$ and $278 \mathrm{~nm}$ with the flow rate of $1.0 \mathrm{~mL} / \mathrm{min}$. The column temperature was retained at $30^{\circ} \mathrm{C}$, and a sample volume of $20 \mu \mathrm{L}$ was injected by an automatic sampler.

\subsection{Laboratory prepared mixture standard solution.}

Precision weighing furosemide, torasemide, azosemide, bumetanide, or etacrynic acid reference each $25.0 \mathrm{mg}$ and immersed in mobile phase in a $50 \mathrm{ml}$ volumetric flask. These stock standard solutions were stored at $4^{\circ} \mathrm{C}$ and warmed up to room temperature before use. The mixed working solutions of the five LDs was taken and mobile phase was added to form a mixed reference solution with a concentration of about $50 \mu \mathrm{g} / \mathrm{ml}$ of the reference substance. 


\subsection{Method Validation}

\subsubsection{Linearity and range}

A series volume of the five LDs mixed standard solutions was based on the analytical condition of Section 2.2 and transferred by volume with $1 \mu \mathrm{L}, 5 \mu \mathrm{L}, 10 \mu \mathrm{L}$, $20 \mu \mathrm{L}, 40 \mu \mathrm{L}$, and $60 \mu \mathrm{L}$ and injected into the columns, respectively. The standard curve of the five LDs were constructed by the different concentration of the mixed solution. Chromatograms were recorded and the standard calibration curve was generated with peak area as the Y-axis (Y) and the concentration $(\mu \mathrm{g} \cdot \mathrm{ml}-1)$ of each standard solutions' as the $\mathrm{X}$-axis (X).

\subsubsection{Precision}

The mixed standard solution at the same concentration was continuously injected six times in the same day or different day according to the chromatographic condition under Section 2.2. The relative standard deviation (RSD) values were evaluated by the chromatographic peak area of the five LDs.

\subsubsection{Stability}

The same mixed working standard solutions was injected into HPLC at $0 \mathrm{~h}, 2 \mathrm{~h}, 4 \mathrm{~h}$, $6 \mathrm{~h}$ and $8 \mathrm{~h}$ with the same mobile phase. The RSD of the five peaks areas were determined.

\subsubsection{Recovery}

The accuracy of the assay method was calculated in triplicate by adding known amounts of the five LDs reference substance to the commercial samples solutions. Each solution was prepared at three concentration levels (i.e., 40, 50, and $60 \mu \mathrm{g} / \mathrm{mL}$ ) and each one was injected into HPLC in triplicate. Then, the peak areas was recorded and the average recovery, RSD \% of each LDs were calculated.

\subsubsection{Durability}

The durability study was examined by three different HPLC instruments which were Dionex U3000, Agilent 1260 series, and Shimadzu LC-20A. Three different models of chromatographic columns were carried out including Agilent Zorbax Extend $\mathrm{C}_{18}$, Shimadzu HC-C $\mathrm{C}_{18}$ column, and Kromasil $\mathrm{C}_{18}(150 \mathrm{~mm} \times 4.6 \mathrm{~mm}, 5 \mathrm{um})$. 
Various $\mathrm{pH}$ values $(3.8,4.0,4.2)$, flow rate $\left(0.98 \mathrm{~mL} \cdot \mathrm{min}^{-1}, 1.0 \mathrm{~mL} \cdot \mathrm{min}^{-1}\right.$, and 1.02 $\left.\mathrm{mL} \cdot \mathrm{min}^{-1}\right)$ of the mobile phase and column temperature $\left(29^{\circ} \mathrm{C}, 30^{\circ} \mathrm{C}\right.$, and $\left.31^{\circ} \mathrm{C}\right)$ was determined. The separation degree and RSD \% of the five LDs was investigated.

\subsection{Qualitative investigation.}

\subsubsection{UV spectral similarity.}

The mixed standard solutions of five LDs were injected into HPLC under the above analytical conditions. The chromatograms map and UV Spectra were recorded and the similarity of the original and first-order spectra of the five LDs was analyzed by the ChemStation software Version $\underline{\text { C. } .01 .10}$ serves.

\subsubsection{Relative capacity factor.}

Under the analytical conditions given in sections 2.2 and 2.4 .5 , the same standard solutions of the five LDs mixtures were tested and peak retention times were recorded to determine relative correction factors (RCFs). The RCFs is calculated by the following formulae [1].

$$
\mathrm{RCF}=\left(\mathrm{t}_{\mathrm{A}}-\mathrm{t}_{0}\right) /\left(\mathrm{t}_{\mathrm{R}}-\mathrm{t}_{0}\right)
$$

Where $t_{0}, t_{R}$ and $t_{A}$ represents the retention time of urine pyrimidine, etacrynic acid, and analyte, respectively.

\subsection{Quantitative Analysis of Multicomponent by a Single Marker (QAMS)}

The application of QAMS method in the quality control of five diuretic drugs is based on the relative correction factor (f) of each component, which is proportional to the detection signal in a certain concentration range. In this study, we selected ethylene acrylic acid as the internal standard, and used equation (2) to calculate the $\mathrm{f}$ of other diuretics.

$$
f=\frac{f_{s}}{f_{i}}=\frac{A_{s} / C_{s}}{A_{i} / C_{i}}
$$

Where $A_{s}$ is the peak area of internal standard (etacrynic acid), $C_{s}$ is the concentration of internal standard (etacrynic acid), $A_{i}$ is the peak area of other investigated components $\mathrm{i}$, and $C_{\tilde{i}}$ is the concentration of other investigated component $\mathrm{i}$ in the sample solution.

According to the equation (2), we can derive the equation (3). 


$$
C i=f \times C_{s} \times \frac{A_{i}}{A_{s}}
$$

We can use the equation (3) to calculate the concentration of each other investigated component in the sample solution. At the same time, the effects of different HPLC systems, $\mathrm{pH}$ value of mobile phase, gradient elution scheme, flow rate, injection volume and column temperature given under section 2.4 .5 for $\mathrm{f}$ were investigated.

\subsection{Analysis of the five LDs in commercial injections}

To determine the content of furosemide, bumetanide, and torasemide, commercially available injections of the 3 diuretics were prepared with mobile phase. To determine the content of azosemide and etacrynic acid in conventional tablets, ten tablets were weighed, and disintegrated by shaking for 1 min with $10 \mathrm{~mL}$ water in a $100 \mathrm{~mL}$ volumetric flask. $40 \mathrm{~mL}$ acetonitrile was added. It was ultrasonic treatment for 20 minutes, and diluted with purified water by the volume of $100 \mathrm{ml}$. Then, the samples of the 5 diuretics were injected into HPLC based on the above analytical method of Section 2.2.

\section{Results and Discussion}

\subsection{Optimization of analytical conditions}

In order to establish a method for the simultaneous determination of five LDs by HPLC with DAD detection. Methanol-water, methanol-water containing triethylamine or phosphoric acid, acetonitrile-water, acetonitrile-water containing phosphoric acid or triethylamine are first performed to separate these compounds, but the selectivity between these five LDs was not optimal. Then we chose $0.05 \mathrm{~mol} / \mathrm{L}$ potassium dihydrogen phosphate with acetonitrile, which provides an alternative selectivity compared to other conditions and thus a better separation between the five LDs. The representative HPLC chromatogram for simultaneous separation of the five LDs with different buffer $\mathrm{pH}$ or acetonitrile content varied are shown in Figure 2 and Figure 3. The mobile phase composed of acetonitrile $-0.05 \mathrm{~mol} / \mathrm{L}$ of $\mathrm{KH}_{2} \mathrm{PO}_{4}(\mathrm{pH}$ adjusted to 4.0 using diluted phosphoric acid) (36: 64, v/v) provided a short analysis time with not exceed 25 min while maintaining acceptable resolution between compounds. 


\subsection{Method Validation}

The liner range, precision, stability, and recovery results were showed in Tables 1 and 2. The linear range of all the five LDs was widely and showed a good linearity relationship $(r>0.999)$. As shown, precision was measured in two parts, by intra-day precision (with RSD values between $0.6 \%$ and $1.8 \%$ ), inter-day precision (with RSD values between $1.4 \%$ and $2.3 \%$ ), which proved the instrument had good precision. The RSD\% of the peak area for furosemide, torasemide, azosemide, bumetanide, and etacrynic acid for stability were $1.1 \%, 0.7 \%, 1.3 \%, 1.1 \%$, and $0.5 \%$, indicating that the sample solutions were stable within 8 hours. The result of recovery revealed that average recovery rate from $97.2 \%$ to $102.1 \% \%$ with $\mathrm{RSD}<1.9 \%$, indicating that the method had good accuracy. All of the above results show that the established methods were effective and reliable.

\subsection{Qualitative investigation.}

\subsubsection{UV Spectral Similarity.}

The similarity of UV spectrum is related to the chemical structure of compounds, and different compounds have different UV absorption spectra, which can be used to characterize the compounds in LDs. The results of the original and first-order spectral similarity of the five diuretics are shown in Table 3-4 and the vector graph of the five diuretics are shown in Figure 4, witch indicating that the first-order spectral after derivation show more characteristic details than the original spectra. The similarity of UV spectrum can be used for the qualitative identification of the five diuretics, which improves the accuracy and more characteristics.

\subsubsection{Relative capacity factor.}

The HPLC method used in the literature mostly uses the retention time to carry on the qualitative analysis. In the multicomponent qualitative analysis, the heavy use of the reference substance increases the detection cost, in the detection process, often cannot realize the rapid obtaining the reference substance, and the retention time is affected by the different instrument, brand of chromatographic column, column temperatures, and flow rates or $\mathrm{pH}$ values of the mobile phase. In addition, the five LDs compound with similar chemical structure and physical property witch indicate it is difficult to qualitative investigation by the retention time of the components. In this 
experiment, the RCFs were choosing as a qualitative analysis index and the robustness of it was investigated. The robustness results of the RCFs for the five LDs is shown in Table 5. The results showed that the RCFs was not affected by different instruments, flow velocity, mobile phase volume, $\mathrm{pH}$ value and column temperature (RSD was less than 5.0\%). For the same system, different HPLC columns gave the RCFs RSD $>31.0 \%$, which failed to satisfy the requirements of qualitative analysis. The differences between RCFs can mainly be attributed to different manufacturers, being associated with the properties and preparation of packing materials. To this end, we herein restricted conditional parameters and performed using spectral similarity as the double indicator to qualify the qualitative analysis.

\subsection{Quantitative study of QAMS.}

Inspired by the HPLC-based ESM analytical method, the QAMS uses a single component as the internal standard to simultaneously quantitative measurements of itself and other analytes by calculating relative correction factors (f). In recent decades, QAMS method has been widely used in the evaluation of a large number of Chinese herbal medicines, chemical drugs and drug impurities. In this study, etacrynic acid was chosen as internal reference to calculate the $f$ of the other four diuretics. To evaluate the robustness of $\mathrm{f}$, the influence of different $\mathrm{pH}$ values of mobile phase, ratio and flow rates of mobile phase, chromatographic column types, chromatographic column temperatures, and injection volumes was investigated. The $f$ of the five LDs were shown in Table 6 . The results show that the $f$ has good repeatability under different analytical conditions, witch ensure that the QAMS method can be well applied to routine analysis.

\subsection{Sample Analysis}

The amounts results of the five LDs samples calculated by HPLC-ESM and HPLC-QAMS are shown in Table 7. Comparative analysis results indicated that there is no significant difference between HPLC-ESM and HPLC-QAMS (RSD values were $<3.0 \%$ ), which shows that the above established method is accurate and reliable.

\section{Conclusion.}

In this paper, method for simultaneous determination of five diuretic drugs by HPLC-ESM and HPLC-QAMS is developed. HPLC-QAMS chose etacrynic acid as 
internal reference material to calculate the relative correction factor of other four diuretics, and the influence factors such as different chromatographic column, instrument, column temperature, mobile phase and flow velocity were investigated. The above established method have been successfully applied to the qualitative identification and quantitative analysis of five LDs. Because the QAMS analysis method can provide reliable results, save reference materials and shorten analysis time, it has great potential and enhanced role in hospital-based quality control and qualitative identification and quantitative analysis of diuretics in other medicinal materials.

\section{Abbreviations}

LDs: Loop diuretics; HPLC: high performance liquid chromatography; QAMS: quantitative analysis of multiple components with a single marker; ESM: external standard method; RSD: relative standard deviation; RCFs: relative calibration factors

\section{Declarations}

\section{Ethics approval and consent to participate}

Not Applicable.

\section{Consent for publication}

Not Applicable.

\section{Availability of data and materials}

The majority of the data used to support the findings of this study are included within the article. Other data are available from the corresponding author upon request.

\section{Competing interests}

The authors declare that there is no conflict of interests regarding the publication of this paper.

\section{Funding}

This study was financially supported by Technology Key Program of Shiyan, China (number 18Y73). 


\section{Authors' contributions}

FCC and BXF provided the loop diuretics drugs and dosage forms, proposed the subject, analyze and interpret of the data, draft the article. PL and SCW designed the assay, conducted its validation, and participated in revision of the manuscript.

\section{Acknowledgements}

The authors acknowledged the support from Renmin hospital of Hubei University of Medcine.

\section{Authors' information}

\section{Affiliations}

Sinopharm Dongfeng General Hospital, Hubei University of Medicine, Shiyan, Hubei, 442008, P.R. China.

Fuchao Chen, Baoxia Fang, Peng Li

School of Pharmacy, Xi'an Jiaotong University, Xi'an, 710061, Shanxi, PR

\section{China.}

Sicen Wang

\section{Reference}

1. Roush GC, Kaur R, Ernst ME (2014) Diuretics: A Review and Update. J Cardiovasc Pharmacol Ther. 19: 5-13.

2. Wile D (2012) Diuretics: a review. Ann Clin Biochem 49: 419-431.

3. Anisman SD, Erickson SB, Morden NE (2019) How to prescribe loop diuretics in oedema. BMJ. 21; 364: 1359.

4. Ng KT, Jll Y (2018) Continuous infusion vs. intermittent bolus injection of furosemide in acute decompensated heart failure: systematic review and meta-analysis of randomised controlled trials. Anaesthesia, 73: 238-247.

5. Cosín J, Díez J (2002) Torasemide in chronic heart failure: results of the TORIC study. European Journal of Heart Failure 4: 507-513.

6. Lykke K, Töllner K, Erker T (2015) Structure-activity relationships of bumetanide derivatives: correlation between diuretic activity in dogs and inhibition of the human NKCC2A transporter. British Journal of Pharmacology 172:4469-4480.

7. Alisky JM, Tuttle TF (2003) Ethacrynic acid can be effective for refractory 
congestive heart failure and ascites. Southern Medical Journal 96:1148-1150.

8. Hampel P, Römermann K, MacAulay N (2018) Azosemide is more potent than bumetanide and various other loop diuretics to inhibit the sodium- potassiumchloride- cotransporter human variants hNKCC1A and hNKCC1B. Scientific Reports 8: 9877.

9. Zhang L, Wang RL, Tian Y (2015).Determination of torasemide in human plasma and its bioequivalence study by high-performance liquid chromatography with electrospray ionization tandem mass spectrometry.Journal of Pharmaceutical Analysis 6: 95-102.

10. Stolarczyk M, Hubicka U, Krzek J (2015). Simultaneous Determination of Eight Hypotensive Drugs of Various Chemical Groups in Pharmaceutical Preparations by HPLC-DAD. Journal of AOAC International 98: 1542-1548.

11. Subramanian V, Nagappan K, Mannemala S (2015) .Optimization and Validation of a Sensitive Method for HPLC-PDA Simultaneous Determination of Torasemide an d Spironolactone in Human Plasma using Central Composite Design. Acta Chimica S1 ovenica 62:633-641.

12. Legorburu M, Alonso RM, Ortiz E (2001). Quantitative determination of the loo $\mathrm{p}$ diuretic bumetanide in urine and pharmaceuticals by high-performance liquid chrom atography with amperometric detection. Journal of Chromatographic Science 39:425530 .

13. Lin CW, Gonzalez P, Yuan F (2011) Cellular pharmacokinetic and pharmacodynamic analyses of ethacrynic acid: implications in topical drug delivery in the eye. Molecular vision 17:2507-2515.

14. Lukáš Zahálka, Sylva Klovrzová, Ludmila Matysová, Zdenka Šklubalová, Petr Solich. (2018) Furosemide ethanol-free oral solutions for paediatric use: formulation HPLC method and stability study. Eur J Hosp Pharm 25:144-149.

15. Naguib IA, Abdelaleem EA, Emam AA, Ali NW, Abdallah FF (2018) Development and validation of HPTLC and green HPLC methods for determination of furosemide spironolactone and canrenone in pure forms tablets and spiked human plasma. Biomedical Chromatography 32(10): e4304.

16. Li J, Guo Z, Zhao X, Han P, Feng S (2015) Simultaneous determination of four drugs for kidney diseases in urine by high performance liquid chromatography. Se pu 33: 1210-1213.

17. Baranowska I, Płonka J (2016) Monitoring of biogenic amines and drugs of 
various therapeutic groups in urine samples with use of HPLC. Biomed Chromatogr. 30 652-657.

18. Baranowska I, Markowski P, Baranowski J (2009) Development and validation of an HPLC method for the simultaneous analysis of 23 selected drugs belonging to different therapeutic groups in human urine samples. Anal Sci 1307-1313.

19. Youm I, Youan BBC (2013) Validated reverse-phase high-performance liquid chromatography for quantification of furosemide in tablets and nanoparticles. J Anal Methods Chem. 2013 1-9.

20. Zhang Z, Wang D, Zhang L, Du M, Chen G (2008) Determination of diuretics in human urine by hollow fiber-based liquid-liquid-liquid microextraction coupled to high performance liquid chromatography. Analyst 1331187-1194.

21. Chen Y, Liu Y (2011) Analytical methods for the determination of anti-diuretic peptides in biological samples: challenges and perspectives. Current Analytical Chemistry 7:117-129.

22. Huan Y, Jie Z, Shang XY, et al. (2018) Multi-Component Analysis of Ilex Kudingcha C. J. Tseng by a Single Marker Quantification Method and Chemometric Discrimination of HPLC Fingerprints. Molecules. 23: 854

23. Li Y, Zhang Y, Zhang Z, Hu Y, Cui X, Xiong Y (2019) Quality Evaluation of Gastrodia Elata Tubers Based on HPLC Fingerprint Analyses and Quantitative Analysis of Multi-Components by Single Marker. Molecules. 24:1521.

24. Zhu C, Li X, Zhang B, Lin Z (2017) Quantitative analysis of multi- components by single marker-a rational method for the internal quality of Chinese herbal medicine. Integr Med Res.6:1-11.

25. Chen LH, Wu Y, Guan YM, Jin C, Zhu WF, Yang M (2018) Analysis of the High-Performance Liquid Chromatography Fingerprints and Quantitative Analysis of Multicomponents by Single Marker of Products of Fermented Cordyceps sinensis. Comp Biochem Physiol 17(3):799-803.

26. Wang S, Xu Y, Wang Y (2017) Simultaneous determination of six active components in Oviductus Ranae via quantitative analysis of multicomponents by single marker. J Anal Methods Chem 2017:9194847.

27. Wang CQ, Jia XH, Zhu S, Komatsu K, Wang X, Cai SQ (2015) A systematic study on the influencing parameters and improvement of quantitative analysis of multi-component with single marker method using notoginseng as research subject. Talanta 134:587-595. 
28. Chen A, Sun L, Yuan H, Wu A, Lu J, Ma S (2017) A holistic strategy for quality and safety control of traditional Chinese medicines by the "iVarious" standard system. J Pharm Anal 7(5):271-279.

29. Chen FC, He XD, Fang BX, Wang SC (2020) Simultaneous Quantitative Analysis of Six Proton-Pump Inhibitors with a Single Marker and Evaluation of Stability of Investigated Drugs in Polypropylene Syringes for Continuous Infusion Use. Drug Design, Development and Therapy, 14: 5689-5698. 


\section{Figure legends}

\section{Figure 1.}

Chemical structure of furosemide (a), torasemide (b), azosemide (c), bumetanide (d) and etacrynic acid (e).

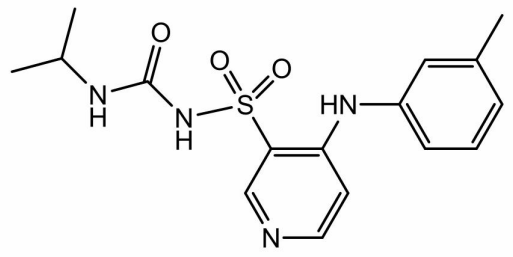

(a)<smiles>C=C(CC)C(=O)c1ccc(OCC(=O)O)c(Cl)c1Cl</smiles>

(b)

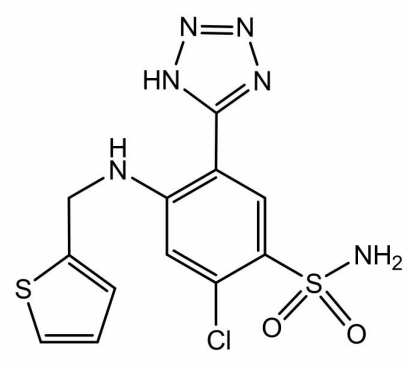

(c)<smiles>NS(=O)(=O)c1cc(C(=O)O)c(NCc2ccco2)cc1Cl</smiles>

(d)<smiles>CCCCNc1cc(C(=O)O)cc(S(N)(=O)=O)c1Oc1ccccc1</smiles>

(e) 
Figure 2.

A typical chromatogram of standard drug mixture samples. Chromatographic conditions were acetonitrile- $0.05 \mathrm{~mol} \cdot \mathrm{L}^{-1}$ potassium dihydrogen phosphate (36: 64, $\mathrm{v} / \mathrm{v}$ ) except the buffer $\mathrm{pH}$ were varied. a. $\mathrm{pH} 3.0$; b. $\mathrm{pH} 3.5$; c. $\mathrm{pH} 4.0$; d. $\mathrm{pH} 4.5$; d. pH 5.0.

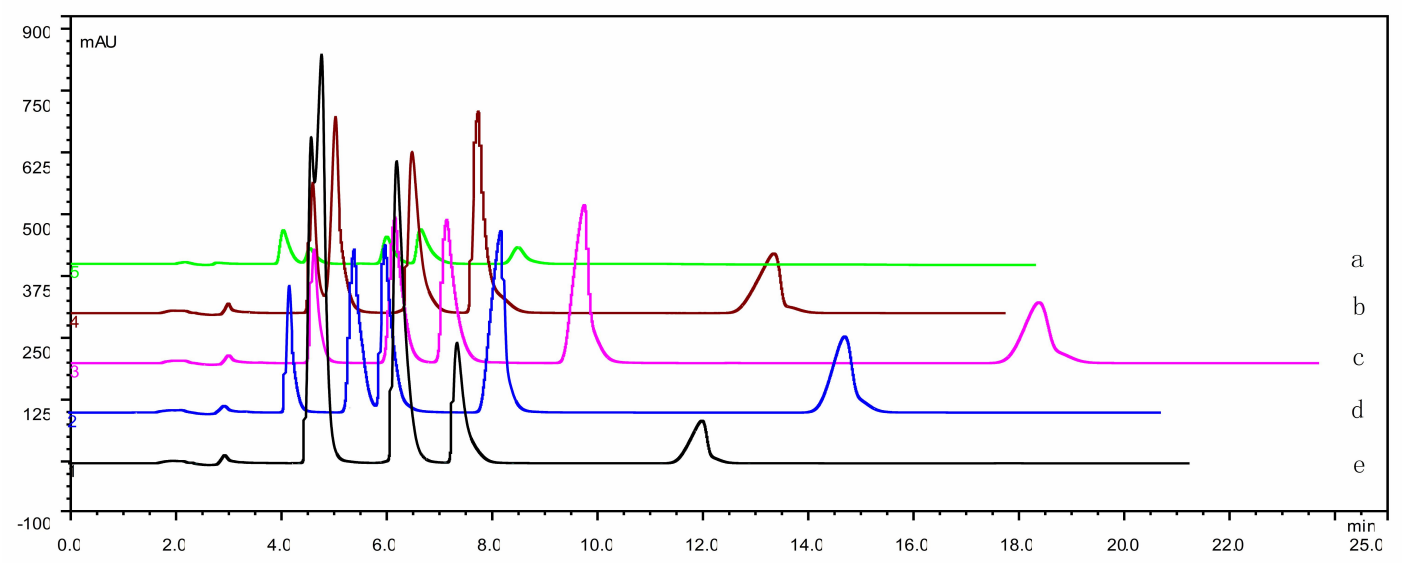


Figure 3.

A typical chromatogram of standard drug mixture samples. Chromatographic conditions were acetonitrile- $0.05 \mathrm{~mol} \cdot \mathrm{L}^{-1}$ potassium dihydrogen phosphate (phosphoric acid to adjust $\mathrm{pH}$ to 4.0 ) except the acetonitrile content were varied. a. acetonitrile content $30 ; \mathrm{b}$. acetonitrile content 34 ; c. acetonitrile content 36 ; d. acetonitrile content 38 ; e. acetonitrile content 40 .

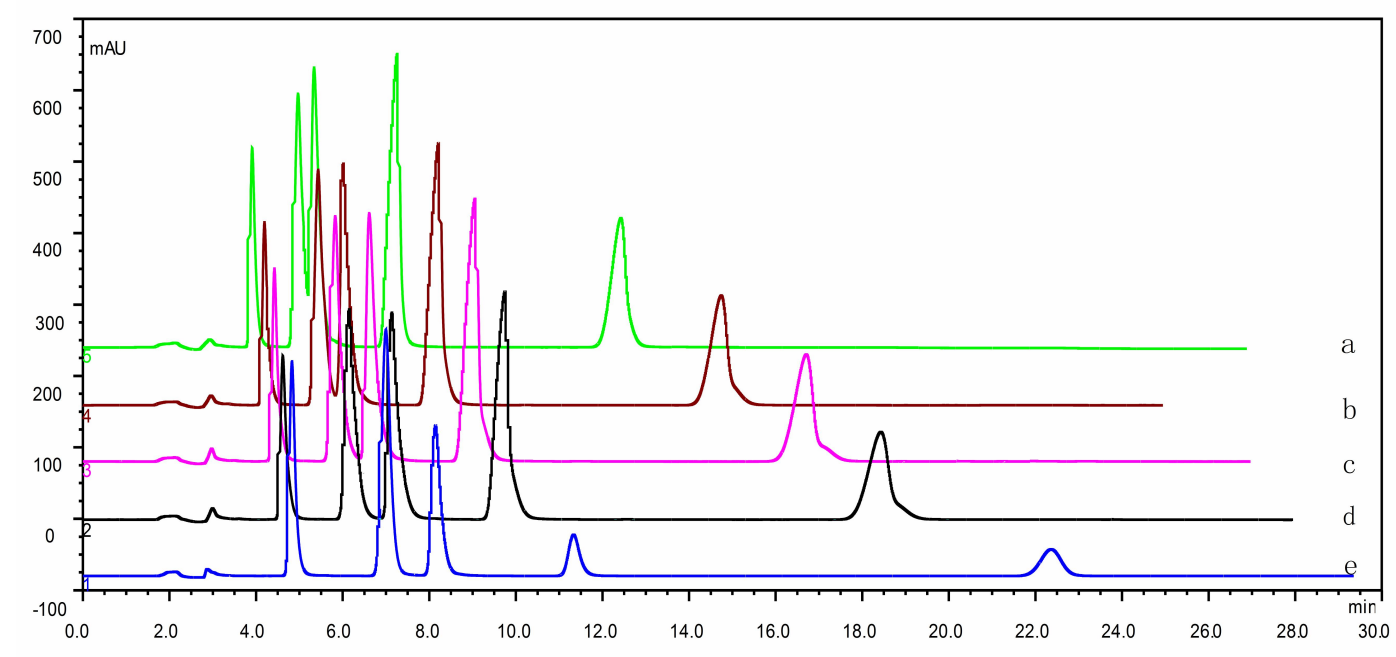


Figure 4.

The UV spectra and 1st UV spectra of furosemide, torasemide, azosemide, bumetanide and etacrynic acid.

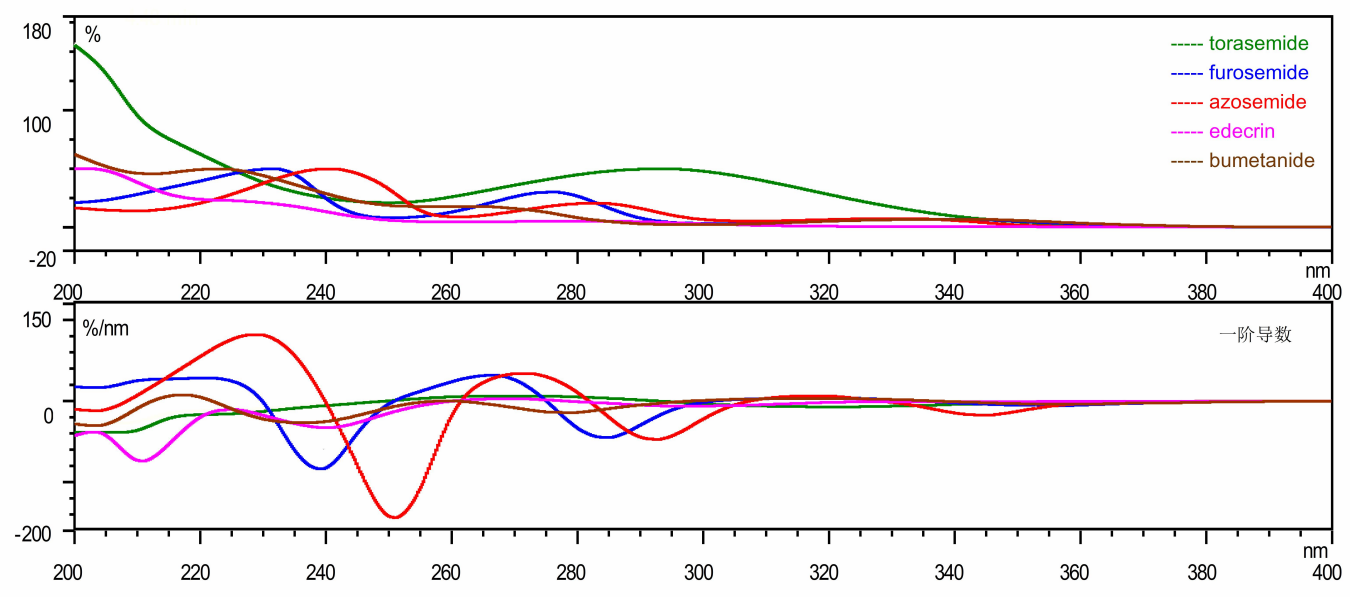


Table 1 Regression equation, correlation coefficient (r), linear range and detection limit of the five diuretic drugs

\begin{tabular}{|c|c|c|c|c|}
\hline Studied drug & Regression Equation & $\mathbf{r}$ & $\begin{array}{c}\text { (Linear Range) / } \\
\left(\boldsymbol{\mu g} \cdot \mathbf{m L}^{-1}\right)\end{array}$ & $\begin{array}{c}\text { (Detection Limit) } \\
/ \mu \mathrm{g} \cdot \mathbf{m L}^{-1}\end{array}$ \\
\hline Etacrynic acid & $y=20.301 x-1.624$ & 0.9993 & $2.5-150$ & 0.25 \\
\hline Torasemide & $y=33.204 x+3.131$ & 0.9998 & $2.5-150$ & 0.08 \\
\hline Furosemide & $y=27.634 x-0.970$ & 0.9999 & $2.5-150$ & 0.05 \\
\hline Azosemide & $y=43.381 x+8.666$ & 0.9992 & $2.5-150$ & 0.13 \\
\hline Bumetanide & $y=36.124 x+1.320$ & 0.9999 & $2.5-150$ & 0.20 \\
\hline
\end{tabular}


Table 2 Recovery test of the developed HPLC analysis method

\begin{tabular}{|c|c|c|c|c|}
\hline Studied drug & $\begin{array}{c}\text { Measured } \\
\text { concentrations } \\
(\mu \mathrm{g} / \mathrm{mL})\end{array}$ & $\begin{array}{c}\text { Accuracy } \\
\%\end{array}$ & $\begin{array}{c}\text { Average } \\
\text { recovery } \\
(\%)\end{array}$ & RSD (\%) \\
\hline \multirow[t]{3}{*}{ Etacrynic acid } & 40.0 & 98.3 & & \\
\hline & 50.0 & 97.7 & 98.8 & 1.4 \\
\hline & 60.0 & 100.4 & & \\
\hline \multirow[t]{3}{*}{ Torasemide } & 40.0 & 96.7 & & \\
\hline & 50.0 & 99.1 & 98.5 & 1.6 \\
\hline & 60.0 & 99.6 & & \\
\hline \multirow[t]{3}{*}{ Furosemide } & 40.0 & 100.6 & & \\
\hline & 50.0 & 102.1 & 100.3 & 1.9 \\
\hline & 60.0 & 98.3 & & \\
\hline \multirow[t]{3}{*}{ Azosemide } & 40.0 & 97.2 & & \\
\hline & 50.0 & 98.2 & 97.9 & 0.7 \\
\hline & 60.0 & 98.4 & & \\
\hline \multirow[t]{3}{*}{ Bumetanide } & 40.0 & 97.5 & & \\
\hline & 50.0 & 100.8 & 99.3 & 1.7 \\
\hline & 60.0 & 99.6 & & \\
\hline
\end{tabular}


Table 3 UV spectra similarity of the five diuretic drugs

\begin{tabular}{lccccc}
\hline Studied drug & Torasemide & Furosemide & Azosemide & Etacrynic acid & Bumetanide \\
\hline Torasemide & 1.0000 & & & & \\
Furosemide & 0.7494 & 1.0000 & & & \\
Azosemide & 0.6574 & 0.8550 & 1.0000 & & \\
Etacrynic acid & 0.9219 & 0.7761 & 0.6553 & 1.0000 & \\
Bumetanide & 0.8965 & 0.8499 & 0.7544 & 0.9451 & 1.0000 \\
\hline
\end{tabular}

Table 4 1st UV spectra similarity of the five diuretic drugs

\begin{tabular}{lccccc}
\hline Studied drug & Torasemide & Furosemide & Azosemide & Etacrynic acid & Bumetanide \\
\hline Torasemide & 1.0000 & & & & \\
Furosemide & -0.1078 & 1.0000 & & & \\
Azosemide & -0.1712 & 0.1698 & 1.0000 & & \\
Etacrynic acid & 0.8132 & 0.0873 & -0.0475 & 1.0000 & \\
Bumetanide & 0.3288 & 0.3369 & 0.0457 & 0.1218 & 1.0000 \\
\hline
\end{tabular}


Table 5 Effects of different instruments, columns, column temperatures, flow rates, volume and pH on RRTs $(n=3)$

\begin{tabular}{|c|c|c|c|c|c|c|}
\hline & Effects Factor & Torasemide & Furosemide & Azosemide & Etacrynic acid & Bumetanide \\
\hline & Chromatographic Columns & 38.95 & 36.77 & 35.97 & - & 31.67 \\
\hline & HPLC Instruments & 1.09 & 1.24 & 3.38 & - & 2.34 \\
\hline \multirow[t]{7}{*}{$\mathrm{RSD} \%$} & Column Temperatures & 1.58 & 1.36 & 0.54 & - & 0.93 \\
\hline & Flow Volume of Mobile Phase & 2.10 & 2.11 & 0.93 & - & 1.22 \\
\hline & Flow Rate of Mobile Phase & 1.22 & 0.75 & 0.40 & - & 0.005 \\
\hline & pH Value of Mobile Phase & 4.87 & 3.21 & 3.99 & - & 3.71 \\
\hline & $\bar{\chi}$ & 0.31 & 0.49 & 0.63 & - & 2.11 \\
\hline & S & 0.001 & 0.001 & 0.001 & - & 0.009 \\
\hline & $\bar{\chi} \pm 3 \mathrm{~S}$ & $0.31 \pm 0.003$ & $0.49 \pm 0.004$ & $0.63 \pm 0.002$ & - & $2.11 \pm 0.028$ \\
\hline
\end{tabular}


Table 6 Relative correction factor of the five diuretic drugs

\begin{tabular}{lccc}
\hline \multicolumn{1}{c}{ Studied drug } & $\begin{array}{c}\text { Wavelength } \\
(\mathbf{n m})\end{array}$ & $\mathbf{R S D} / \%$ & $\begin{array}{c}\text { Relative Correction } \\
\text { Etacrynic acid }\end{array}$ \\
Torasemide & 277 & - & 1 \\
Furosemide & 292 & 0.18 & 0.3232 \\
Azosemide & 334 & 0.35 & 0.9024 \\
Bumetanide & 326 & 0.63 & 0.8064 \\
\hline
\end{tabular}

Table 7 Results of the comparison of the five diuretic drugs

\begin{tabular}{lcccc}
\hline & \multicolumn{2}{c}{ the QAMS Methods } & \multicolumn{2}{c}{ the ESM Methods } \\
\cline { 2 - 5 } Studied drug & Accuracy & RSD & Accuracy & RSD \\
& $(\mathbf{\%})$ & $\mathbf{( \% )}$ & $\mathbf{( \% )}$ & $\mathbf{( \% )}$ \\
\hline Etacrynic acid tablet & 95.1 & 2.1 & 96.2 & 1.9 \\
Torasemide injection & 97.4 & 1.3 & 96.8 & 1.4 \\
Furosemide injection & 103.2 & 0.7 & 102.9 & 1.0 \\
Azosemide tablet & 98.5 & 1.8 & 99.1 & 2.2 \\
Bumetanide injection & 102.4 & 1.6 & 101.6 & 1.4 \\
\hline
\end{tabular}


Figures

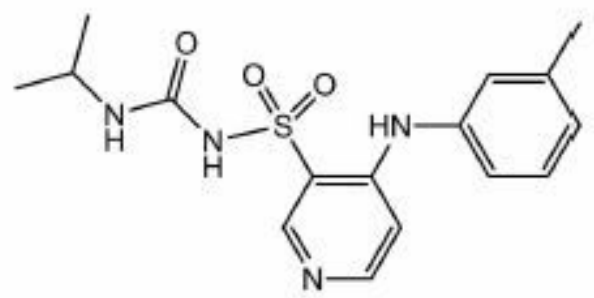

(a)<smiles>C=C(CC)C(=O)c1ccc(OCC(=O)O)c(Cl)c1Cl</smiles>

(b)<smiles>NS(=O)(=O)c1cc(-c2nnn[nH]2)c(NCc2cccs2)cc1Cl</smiles>

(c)<smiles>NS(=O)(=O)c1cc(C(=O)O)c(NCc2ccco2)cc1Cl</smiles>

(d)<smiles>CCCCNc1cc(C(=O)O)cc(S(N)(=O)=O)c1Oc1ccccc1</smiles>

(e)

Figure 1

Chemical structure of furosemide (a), torasemide (b), azosemide (c), bumetanide (d) and etacrynic acid (e).

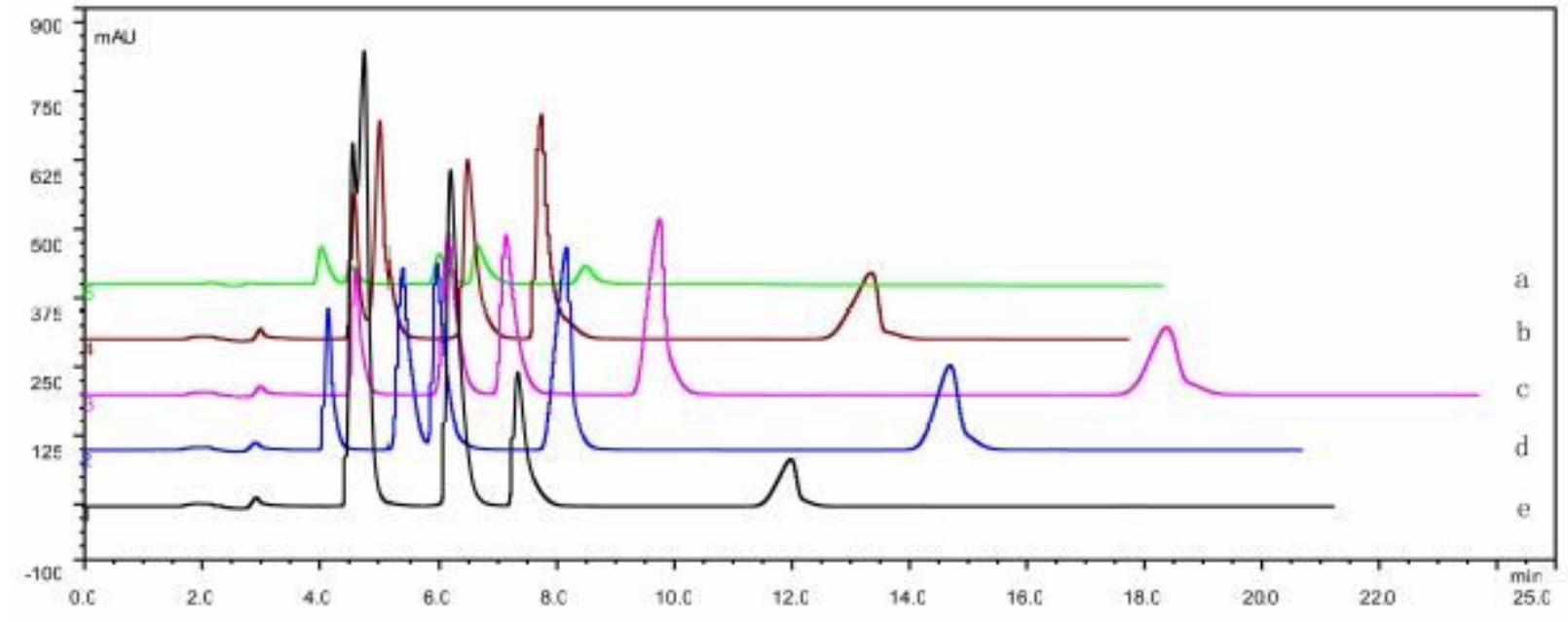


Figure 2

A typical chromatogram of standard drug mixture samples. Chromatographic conditions were acetonitrile- $0.05 \mathrm{~mol} \cdot \mathrm{L}-1$ potassium dihydrogen phosphate $(36: 64, \mathrm{v} / \mathrm{v})$ except the buffer $\mathrm{pH}$ were varied. a. $\mathrm{pH} 3.0$; b. pH 3.5; c. pH 4.0; d. pH 4.5; d. pH 5.0.

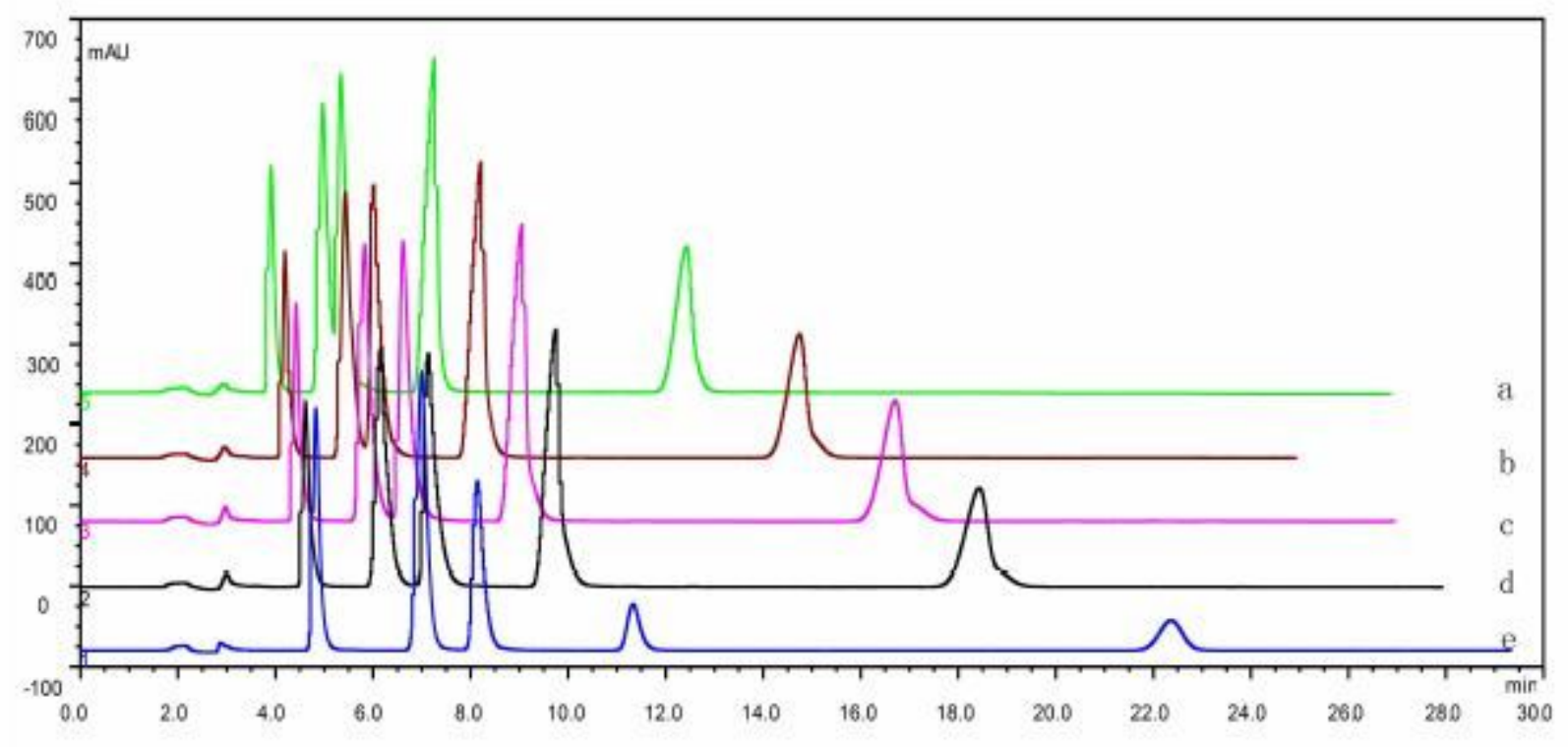

Figure 3

A typical chromatogram of standard drug mixture samples. Chromatographic conditions were acetonitrile- $0.05 \mathrm{~mol} \cdot \mathrm{L}-1$ potassium dihydrogen phosphate (phosphoric acid to adjust $\mathrm{pH}$ to 4.0 ) except the acetonitrile content were varied. a. acetonitrile content 30 ; b. acetonitrile content 34 ; c. acetonitrile content 36; d. acetonitrile content 38; e. acetonitrile content 40.

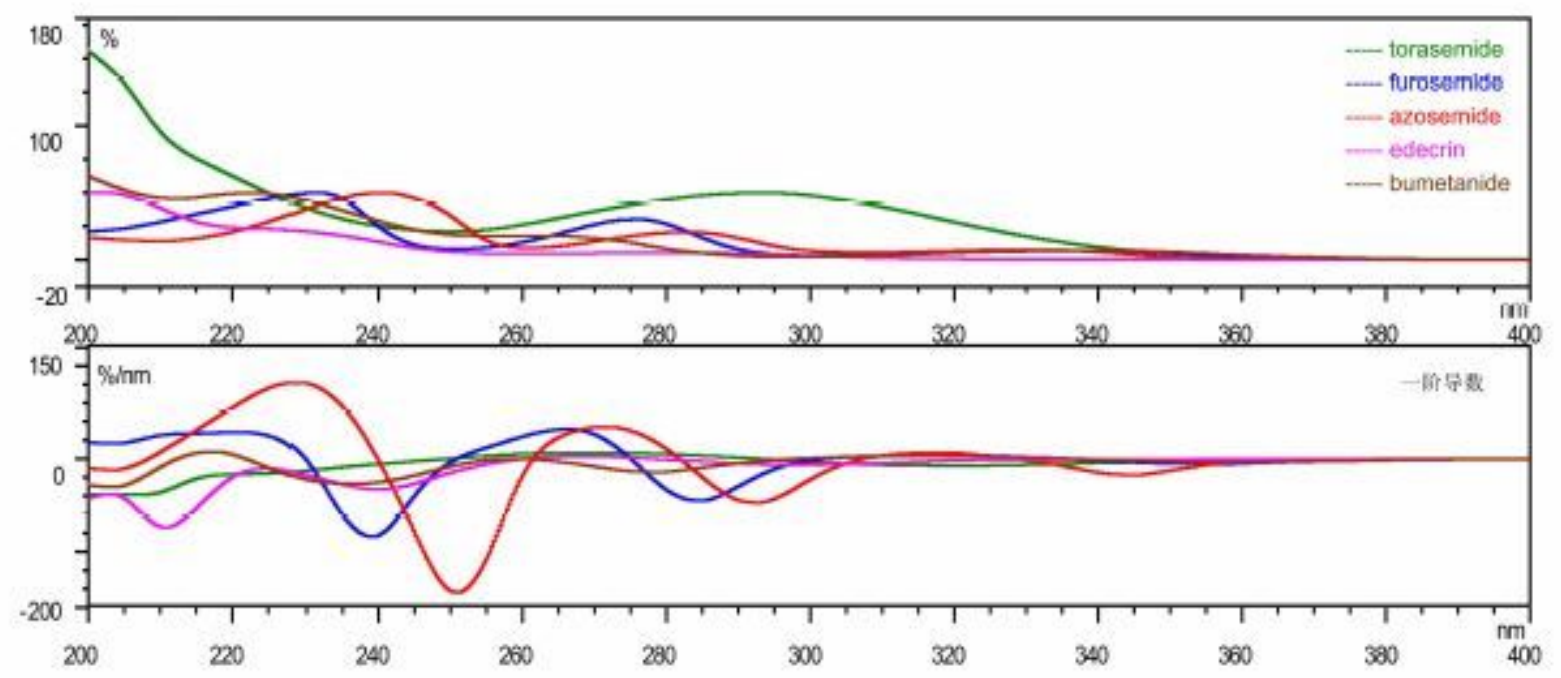

Figure 4 
The UV spectra and 1st UV spectra of furosemide, torasemide, azosemide, bumetanide and etacrynic acid. 